\title{
Operating Temperature Effect on the Thin Film Solar Cell Efficiency
}

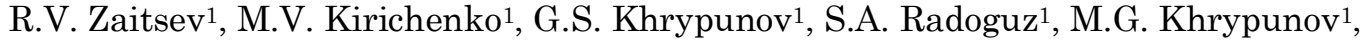 \\ D.S. Prokopenko ${ }^{1}$, L.V. Zaitseva ${ }^{2}$ \\ 1 National Technical University "Kharkov Polytechnic Institute», 2, Kyrpychov St., 61002 Kharkiv, Ukraine \\ 2 Zhukovsky National Aerospace University "Kharkiv Aviation Institute», 17, Chkalov St., 61000 Kharkiv, Ukraine
}

(Received 20 December 2018; revised manuscript received 07 August 2019; published online 22 August 2019)

\begin{abstract}
The made research results of the dependence of the film photovoltaic converter efficiency on their operating temperature and their comparison are considered in the paper. The physical mechanisms of temperature influence analysis on output, diode and electronic parameters of photovoltaic converters were conducted. The output parameters determination of the flexible photovoltaic converters was carried out by measurement of light current-voltage characteristics by using illuminator based on powerful semiconductor LEDs with different colors for simulated radiation which is close to the standard ground and ultraviolet solar spectrum. For ensuring effective non-destructive switching of the test specimens of the flexible PVC based on cadmium telluride to the measurement circle, the special contact device was developed and used. The main feature of contact device is four separate vertically moving metal probes in form of semi spheres with polished surfaces, which makes it impossible to puncture the PVC electrodes. These probes have possibility of individual positioning of each probe that is carried out with the help of a hard rotary console of variable length attached to the body and can be pressed with a given effort without impact on the frontal and any rear electrodes of the PVC experiments. The efficiency temperature coefficients of the photovoltaic converter, which make up for devices with a CdTe of $0.14 \% / \mathrm{C}$, CuInSe $2-0.36 \% / \mathrm{C}$, amorphous silicon - $0.21 \% / \mathrm{C}$ were obtained. The analytical processing and analysis of the light diode characteristic effect on the PVC efficiency based on the CdTe showed that the temperature stability of their efficiency is ensured by the diode current density, the incision of which increases by $50 \%$ from $1.9 \cdot 10^{-9} \mathrm{~A}$ to $2.7 \cdot 10^{-9} \mathrm{~A}$ with the temperature rise from $20^{\circ} \mathrm{C}$ to $50^{\circ} \mathrm{C}$. At the same time, it has been established for PVC on the CuInSe and amorphous silicon base that the decrease of short circuit current density, open circuit voltage and fill factor of current-voltage characteristics plays the main role in efficiency reduction with rising temperature.
\end{abstract}

Keywords: Photovoltaic converters, Solar cells, Thin films, Efficiency, Output and diode parameters, Working temperature.

\section{INTRODUCTION}

At present, the solar thermal collectors are used for thermal conversion, the efficiency of which reaches 70$80 \%$ due to the selective coating application with absorption coefficient in the spectral range of sunlight to 95-98\% and the reflection coefficient in the infrared range of no more than 5-7\%. The current tendency in the development of the most commonly used automated systems of heat collectors with compulsory heating circulator is that the electric energy for their operation is generated by traditional silicon solar modules [1]. As far as traditionally sunny modules are placed separately from solar thermal collectors, this does not lead to an increase in the solar energy efficiency.

In recent times, the development of the combined solar cells has begun actively, in which the thermal energy is utilized during the development of electric energy. The current trend in the development of the most common systems of heat collectors with the forced circulation of heat-carrier is that the electric energy for their operation is generated by traditional silicon solar modules. Since the solar modules are traditionally located separately from solar thermal collectors, this does not lead to the increase in efficiency of using solar energy.

The reducing the use of space for such systems may be due to the combination of photovoltaic converters (PVC) with the system of heat collector. This is realized due to the use of flexible film PVC [2], which can be placed on the surface of the collector plate by repeating the features of its micro relief with the effective thermal contact provision. The PVC, for use in such systems, should effectively generate electrical energy at a working temperature of 50 to $55^{\circ} \mathrm{C}$; they must also provide a solar absorption coefficient of at least $90 \%$ and have an attenuation coefficient of up to $10 \%$ in the infrared spectrum. Together with the cooling system [3] of the heat collector, the PVC design should provide a difference between the PVC temperature and the heat carrier temperature not exceeding $5{ }^{\circ} \mathrm{C}$. When the last two conditions are fulfilled, a selective coating can be chosen from the design of the solar collector, as far as its functions will be performed by the PVC.

The main optimization problem for such a system development is to determine the level of influence of the collector working temperature on the rate of reduction of the film PVC efficiency.

\section{EXPERIMENTAL TECHNIQUE}

The output parameters determination is the main stage of the experimental tests of the flexible PVC. For this purpose, the light current-voltage characteristics (CVC) $[4,5]$ were measured when irradiated with light, the spectral composition of which is close to sunlight. The solar radiation reproduction prevents the receiving of an LED illuminator (Fig. 1) [6]. In the design of the light-emitting block, powerful semiconductor LEDs of different colors are used, which, at low inertia and energy consumption, allow conducting expressive and 
economic studies in conditions of the sufficient approximation of the simulated radiation to the standard ground and ultraviolet solar spectrum.

The concept of a contact device (CD) was developed to provide an effective non-destructive switching of the test specimens of the flexible PVC based on cadmium telluride (Fig. 2). In accordance with this concept, the CD has four separate cylindrical Fluor plastic heads, equipped with only vertically moving metal probes (one in each body), which, with the help of individual springs with controlled rigidity and eccentric elevators, can be pressed with a given effort without impact to the frontal and any rear electrodes of the PVC experiments. The working limbs of the zone-viruses are the semi spheres with polished surfaces, which makes it impossible to puncture the PVC electrodes. To study the parameters of the PVC samples on the polyamide substrate, the diameter of the indicated hemisphere is $4 \mathrm{~mm}$.

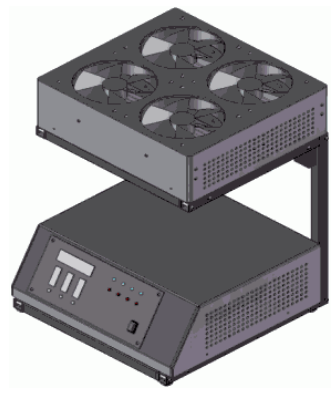

Fig. 1 - Laboratory sample of the LED illuminator from the experimental stand composition

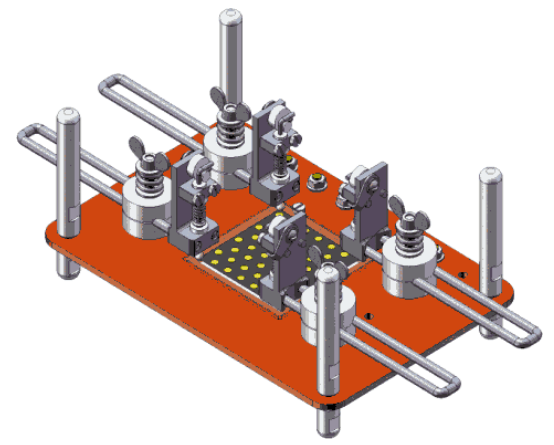

Fig. 2 - CD sketch from the experimental stand composition

The individual positioning of each probe is carried out with the help of a hard rotary console of variable length attached to the body of the Fluor plastic head. Each probe is connected to a flexible copper wire under Fluor plastic isolation from the corresponding connector on a rigid rectangular action-lecture thematic table. The table is the base for mounting cantilever racks (which also allow to adjust the distance of the consoles to the table level) and test PVC samples under a rectangular aperture in the center of the table, through which the irradiation is carried out.

\section{RESULTS AND ITS DISCUSSION}

The key operating parameters that affect the output parameters and, therefore, the efficiency of the solar panel, is the light intensity and the working temperature of the PVC. The solar radiation intensity entering the surface of the PVC due to the change in the concentration of generating under the influence of light of no equilibrium charge carriers determines not only the value of the produced PVC of electric power, but also its efficiency. The solar radiation intensity entering the surface of the PVC depends on the geographical location of its operation and varies according to the time of day and time of the year. The use of systems of solar radiation concentration allows a wide range of values to vary the radiation intensity emitted on the surface. The increase in the intensity of the illumination coming to the photo taking surface of the PVC leads to an increase in the initial parameters. So, the short-circuit current of the PVC increases in proportion to the intensity of the illumination, and the idle voltage increases in proportion to the logarithm of intensity. Consequently, the produced electric power of the PVC is superficially increasing with the increase in the intensity of illumination. Therefore, increasing intensity of lighting is a factor that allows to increase the PVC efficiency. However, it should be noted that the increase in the light intensity also leads to a significant increase in the working temperature of the PVC. In addition, the solar radiation intensity at the operating temperature of the PVC is influenced by the ambient temperature. As the temperature rises, the PVC efficiency decreases. Thus, the working temperature of the photoelectric module (PEM) is a critical factor that determines the PEM efficiency.

The PVC output parameters, which change under the influence of temperature, are the short-circuit current density $J_{S C}$, the idle speed $U_{O C}$, and the factor of filling $\mathrm{FF}$ of the light CVCs.

The dependence of the $J_{S C}$ on the temperature is conditioned by the presence of the connection of this output parameter with the diffusion length of the nonmain carrier-charge $L=(\mu k T \tau / q)^{1 / 2}(\mu$ is the mobility, $\tau$ is the lifetime, $T$ is the temperature, $k$ is the Boltzmann constant, $q$ is the electron charge). If the PVC has a high initial value of the collecting coefficient of the light generated by the non-equilibrium charge carriers, then the changes in $L$ when the temperature changes affect the value of $J_{S C}$ are insignificant. However, in an PVC with a low initial value of the build-up coefficient of the change in $L$, it can essentially affect the photocurrent $J_{S C}$, and, hence, the current of the short circuit.

The connection of the lifetime $\tau$ of minority charge carriers and temperature is complex due to the fact that during the lifetime of the non-equilibrium charge carriers generated under the influence of light, the mutual positions of the energy levels of the recombination centers and quaternary Fermi levels, as well as the temperature dependence of the capture crosssections of these centers, are influenced. For example, for a donor-type recombination center, the lifetime of electrons varies in proportion to $T^{3 / 2}$. The temperature dependence of the mobility of the carriers in the series can most often be represented as $\mu \sim T m$, where the index of degree $m$ is determined by the main scattering mechanism. A slight displacement of the optical absorption edge at variations in temperature causes the change in the $J_{S C}$ due to the dependence of the width of the forbidden zone $E_{g}$ on temperature, but this change 
is not large and makes $\approx 0.03 \% /{ }^{\circ} \mathrm{C}$. According to the experimental data, in most high-quality PVC, the $J_{S C}$ frequency grows with temperature.

The values of $U_{O C}$ and $F F$ decrease with increasing temperature, which is caused mainly by the increase in the concentration of proper charge carriers $n_{i}$. In the general case, with the value of the ideal coefficient of the equation $\mathrm{A}=1$, the relation [7] holds:

$$
U_{O C}=(k T / q) \ln \left(J_{S C} / J_{0}\right) .
$$

In this case, the density of the diode saturation current $J_{0}$ increases exponentially with an increase in $T$ :

$$
J_{0}=C T^{3}(L / \tau) \exp \left(-E_{g} / k T\right),
$$

where the parameters that do not depend on the temperature are bounded in the form of constant $C$.

Taking into account this expression for the dependence of the on-pole idling on temperature, we obtain:

$$
U_{O C}=E_{g} / q-(k T / q) \ln \left(C T^{3}(L / \tau) / J_{S C}\right),
$$

which leads to almost linear decrease of $U_{O C}$ with increasing $T$.

Usually $F F$ decreases quite sharply with increasing temperature and its changes can be calculated using the following expressions:

$$
\begin{gathered}
\beta=1 /\left[1+\ln \left(\beta J_{P H} / J_{0}\right)\right], \\
F F=(1-\beta) \ln \left(\beta J_{P H} / J_{0}\right) / \ln \left(J_{P H} / J_{0}\right) .
\end{gathered}
$$

In order to determine the magnitude of the influence of the working temperature on the parameters of film PVC, a wide spectrum of research studies of film PVC was conducted. Industrial samples were selected for research using the CdS/CdTe (CT series), based on $\mathrm{CuInSe}_{2}$ (CS series) and amorphous silicon (AS series).

Light specimens were measured for all specimens at temperatures from $0{ }^{\circ} \mathrm{C}$ to $60^{\circ} \mathrm{C}$. As a result of more analytical processing of experimental light CVC, the initial parameters and light CVC of the PVC were determined.

The investigated film PVC based on the CdS/CdTe system of the CT series (Fig. 3) had baseline values of efficiency at 7-8\% (Table 1). The analysis shows that with increasing temperature for all investigated samples, there is a practically linear decrease in efficiency (Fig. 3a). At the same time, the reduction factor, which describes the relative change in the efficiency at a temperature change of one degree, is only $-0.14 \mathrm{rel} . \% /{ }^{\circ} \mathrm{C}$, which is much lower than the same parameter for silicon samples. For the idle voltage and the short-circuit current density, there is also a decrease in their values when the operating temperature increases (Fig. 3b, c). Experimentally it was established that the factor of filling the light CVC practically does not change with increasing temperature (Fig. 3g).

The analysis of world diode characteristics shows that the observed decrease in the efficiency is accompanied by an increase in the density of the diode current saturation (Fig. 4a). There was also a decrease in the successive resistance (Fig. 4b). Along with the samples, a similar study of PVC based on the $\mathrm{CuInSe}_{2}$ compound was also conducted. Film PVC CS series have a baseline value of efficiency at the level of $8-10 \%$ (Table 2). The analysis of the conducted parameters shows that for such samples, there is also a linear decrease in the efficiency with increasing temperature (Fig. 5). The corresponding reduction factor for the considered samples is $0.36 \mathrm{rel} . \% /{ }^{\circ} \mathrm{C}$, which is much lower than the same parameter for silicon viscosity, but higher than the coefficient for the PVC of the CS series. There is a decrease in the idle and short-circuit current density at an increase in the operating temperature.
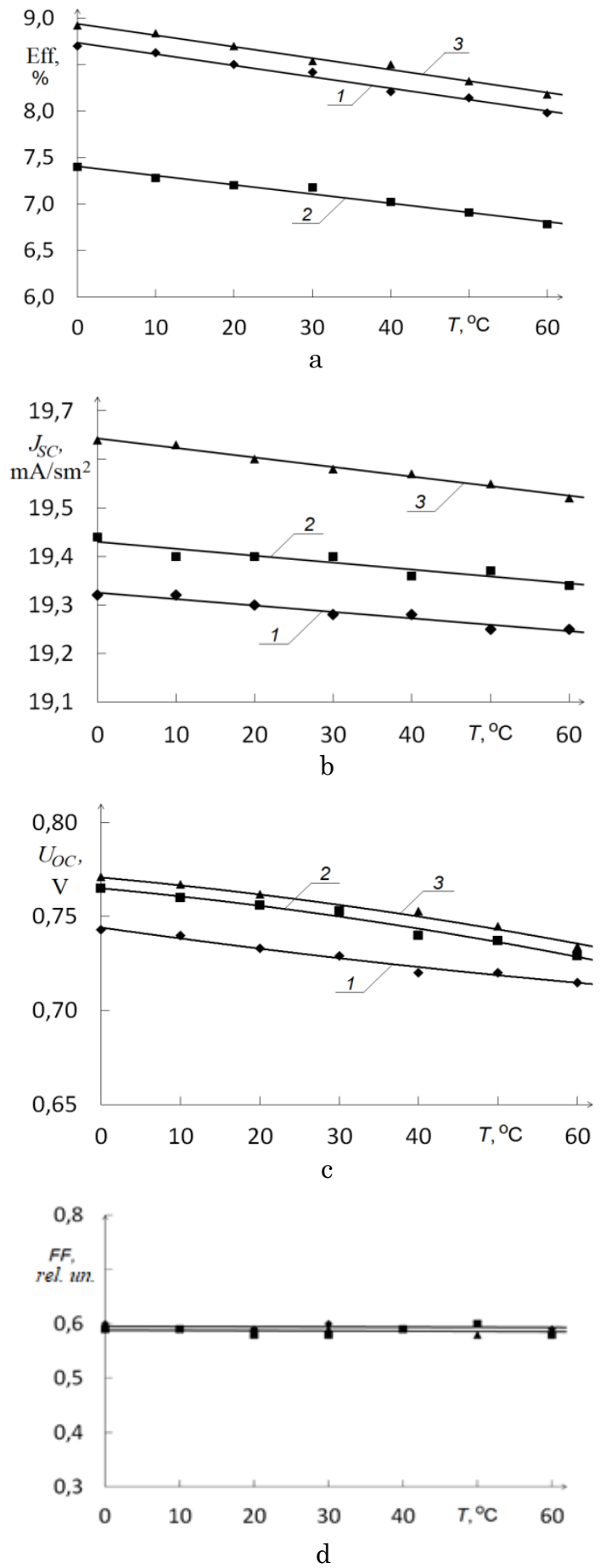

Fig. 3 - The nature of the influence of the working temperature on the efficiency (a), the short-circuit current density (b), the idle voltage (c) and the factor of filling the light-emitting diode (d) of the 1-3 film PVC of the CT series 
Table 1 - Output parameters and light diode characteristics of film PVC CT series at a temperature of $25^{\circ} \mathrm{C}$

\begin{tabular}{|c|c|c|c|}
\hline \multirow{2}{*}{$\begin{array}{l}\text { Output parameters } \\
\text { and light diode } \\
\text { characteristics }\end{array}$} & \multicolumn{3}{|c|}{ Example of CT series } \\
\hline & 1 & 2 & 3 \\
\hline$J_{S C}, \mathrm{~mA} / \mathrm{cm}^{2}$ & 19.3 & 19.4 & 19.6 \\
\hline$U_{O C}, \mathrm{mV}$ & 733 & 756 & 762 \\
\hline$F F$, rel. un. & 0.59 & 0.51 & 0.58 \\
\hline Efficiency, \% & 8.5 & 7.2 & 8.7 \\
\hline$J_{P H}, \mathrm{~mA} / \mathrm{cm}^{2}$ & 19.6 & 19.9 & 19.8 \\
\hline$R_{S}, \mathrm{Ohm} \cdot \mathrm{cm}^{2}$ & 5.8 & 8.2 & 8.7 \\
\hline$R_{\mathrm{SH}}, \mathrm{Ohm} \cdot \mathrm{cm}^{2}$ & 2300 & 1520 & 1890 \\
\hline$A_{i}$, rel. un. & 2.2 & 1.8 & 1.9 \\
\hline$J_{0}, \mathrm{~A} / \mathrm{sm}^{2}$ & $1.1 \cdot 10^{-9}$ & $5.9 \cdot 10^{-9}$ & $2.3 \cdot 10^{-9}$ \\
\hline
\end{tabular}

Table 2 - Output parameters of film PVC of the CS series at a temperature of $25^{\circ} \mathrm{C}$

\begin{tabular}{|c|c|c|c|}
\hline Output parameters & \multicolumn{3}{|c|}{ Example of CS series } \\
\cline { 2 - 4 } $\begin{array}{c}\text { and light diode } \\
\text { characteristics }\end{array}$ & 1 & 2 & 3 \\
\hline$J_{S C}, \mathrm{~mA} / \mathrm{sm}^{2}$ & 25.2 & 23.2 & 21.8 \\
\hline$U_{O C}, \mathrm{mV}$ & 720 & 684 & 701 \\
\hline$F F$, rel. un. & 0.72 & 0.73 & 0.72 \\
\hline Efficiency, \% & 11.5 & 10.2 & 9.7 \\
\hline
\end{tabular}
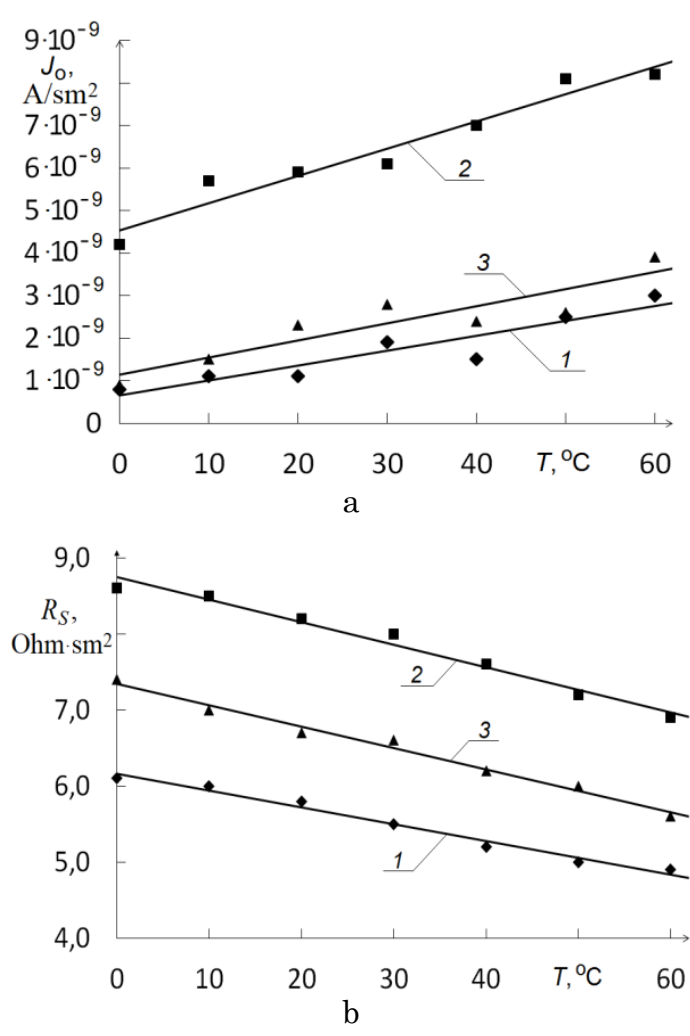

Fig. 4 - The nature of the influence of the working temperature on the density of the diode current saturation (a) and the successive (b) support of the investigated 1-3 film PVC of the CT series

The PVC study based on amorphous silicon of the AS series also showed a decrease in the PVC efficiency with increasing operating temperature. Film PVC of the AS series had the bases of the efficiency at the level of 8$10 \%$ (Table 3 ). For samples of the AS series, there is also line reducing of the efficiency with increasing temperature (Fig. 6). The efficiency reduction coefficient for the considered samples is equal to $-0.21 \mathrm{rel} . \% / \mathrm{C}$. There are analogical effects of reducing the idle speed and short-circuit current density for all film PVC at an increase in the working temperature.

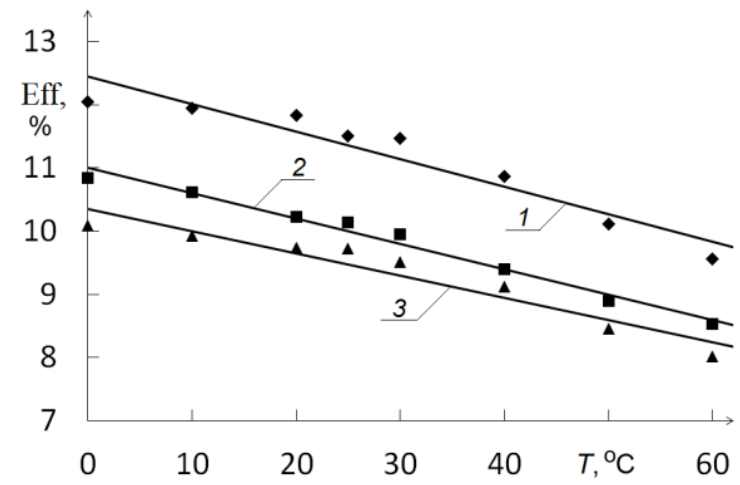

Fig. 5 - The nature of the operating temperature effect on the efficiency of the 1-3 film PVC of the CS series

Table 3 - The film PVC output parameters of the AS series at a temperature of $25^{\circ} \mathrm{C}$

\begin{tabular}{|c|c|c|c|}
\hline Output parameters & \multicolumn{3}{|c|}{ Example of AS series } \\
\cline { 2 - 4 } $\begin{array}{c}\text { and light diode } \\
\text { characteristics }\end{array}$ & 1 & 2 & 3 \\
\hline$J_{S C}, \mathrm{~mA} / \mathrm{sm}^{2}$ & 23.1 & 21.3 & 22.2 \\
\hline$U_{O C}, \mathrm{mV}$ & 680 & 654 & 653 \\
\hline$F F$, rel. un. & 0.73 & 0.71 & 0.71 \\
\hline Efficiency, \% & 9.32 & 8.02 & 8.40 \\
\hline
\end{tabular}

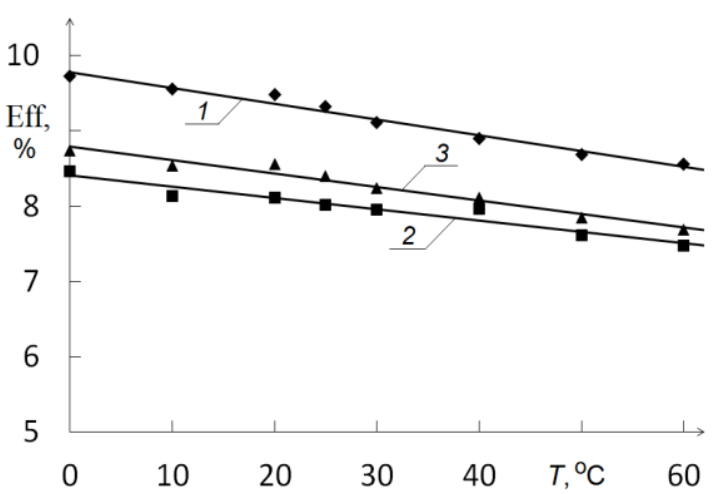

Fig. 6 - The nature of the working temperature effect on the efficiency of the investigated 1-3 film PVC of the AS series

According to the experimental data obtained for all film PVC, there is a decrease in the efficiency at - 0.14-0.36 rel. $\% /{ }^{\circ} \mathrm{C}$ (Table 4 and Fig. 7), which is considerably lower than the similar parameter for silicon photovoltaic converters [8].

This is due to the fact that the short-circuit current density and the idle voltage collapse considerably more slowly with increasing operating temperature, and the factor of filling the light-emitting diodes does not change practically in the same way.

The analysis of the obtained temperature dependences for the film PVC is based on the traditional decrease of parameters with increasing temperature, which correlates with the data of the leading world pro- 
ducers (Calyxo GmbH, Germany). In such a photovoltaic converter, in comparison with silicon, there are no additional mechanisms that reduce the efficiency of the device with increasing temperature. For the studied samples of the film PVC based on the structure of CdS/CdTe, there is no significant decrease in efficiency with increasing temperature to $60^{\circ} \mathrm{C}$.

Table 4-Experimentally obtained coefficients of the film PVC efficiency reduction and their band gap width

\begin{tabular}{|l|l|l|}
\hline Series & $\begin{array}{l}\text { Efficiency re- } \\
\text { duction to tem- } \\
\text { perature ratio, } \\
\% / \mathrm{CC}\end{array}$ & $\begin{array}{l}\text { Width of a band } \\
\text { gap, eB }\end{array}$ \\
\hline $\mathrm{CT}(\mathrm{CdTe})$ & -0.14 & $1.44[9]$ \\
\hline $\mathrm{GaAs}$ & $-0.16[10]$ & $1.43[10]$ \\
\hline $\mathrm{AS}(\mathrm{am} . \mathrm{Si})$ & -0.21 & $1.2-1.3[10,11]$ \\
\hline $\mathrm{CS}(\mathrm{CuInSe})$ & -0.36 & $1.04-1.07[9]$ \\
\hline
\end{tabular}

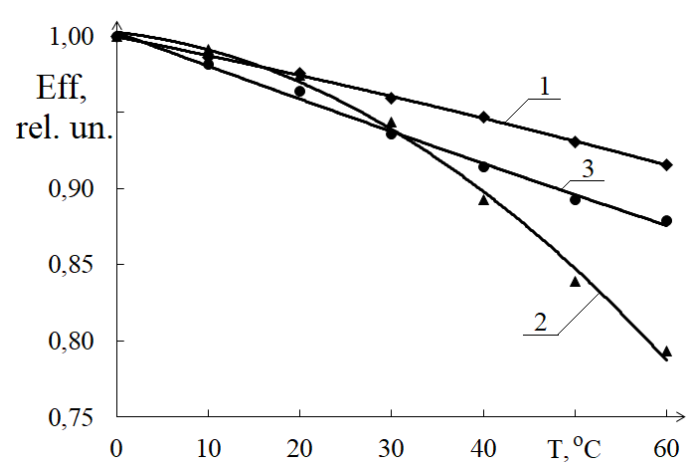

Fig. 7 - The film PVC efficiency relative reduction with increasing the working temperature: 1 -based on CdTe (CT series); 2 - on the basis of CuInSe (CS series); 3 - on the basis of amorphous silicon (AS series)

The experimentally obtained values of the temperature coefficient of efficiency effectively coincide well with literary sources $[10,11]$, and their significance for the considered single-transition film PVC quite accu-

\section{REFERENCES}

1. Fayaz Hussain, R. Nasrin, Md. Hasanuzzaman, N.A. Rahim, Sol. Energ. 169, 217 (2018).

2. G.S. Khrypunov, G.I. Kopach, R.V. Zaitsev, A.I. Dobrozhan, M.M. Harchenko, J. Nano- Electron Phys. 9 No 2, 02008 (2017).

3. R.V. Zaitsev, M.V. Kirichenko, G.S. Khrypunov, R.P. Migushchenko, L.V. Zaitseva, IEEE International Young Scientists Forum on Applied Physics and Engineering (YSF-2017), 112 (Ukraine: Lviv, 2017).

4. J.L. Gray, The Physics of the Solar Cell in Handbook of Photovoltaic Science and Engeeniring (New York: John Wiley \& Sons Ltd: 2011).

5. M.V. Kirichenko, R.V. Zaitsev, V.R. Kopach, Telecommunications and Radio Engineering 69 No 5, 441 (2010). rately correlates with the band gap width of the corresponding absorbing semiconductor material (Table 4). The temperature coefficient of efficiency is proportional to the increase in the band gap width of the base semiconductor material.

Among the film PVC, the most stable values of the output parameters and efficiency are marked by PVC based on the compounds CdTe $(-0.14 \mathrm{rel} \% / \mathrm{o}$ ) and GaAs $\left(-0.16 \mathrm{rel} . \% /{ }^{\circ} \mathrm{C}\right)$ [10]. However, GaAs based on PVCG is only made in a crystalline form, but cannot be adapted for use on the surface of a heat collector plate. Therefore, the PVC on sonnet CdTe is the optimal solution for the creation of a combined photovoltaic system based on the heat collector.

\section{CONCLUSIONS}

The comparison of the study of the temperature dependence of efficiency for film PVC on the basis of CdTe and $\mathrm{CuInSe}_{2}$ compounds produced in laboratory conditions, amorphous silicon and crystalline GaAs, which are manufactured industrially, showed that device structures on the basis of base layers of cadmium telluride have the least reduction in the efficiency with the growth of the operating temperature. With a change in temperature at $50{ }^{\circ} \mathrm{C}$, the efficiency of such devices is reduced by only $1 \%$, and the relative rate of decrease is $-0.14 \mathrm{rel} \% / \mathrm{C}$, which is significantly less than the same for other types of PVC: GaAs - 0.16 rel. \%/C, amorphous silicon -0.21 rel. \%/C, CuInSe $2-0.36$ rel. \%/C.

The analytical processing and analysis of the influence of light diode characteristics on the PVC efficiency on the basis of cadmium telluride showed that the temperature stability of their efficiency is ensured by the diode current density of the cut. When the temperature rises from $20^{\circ} \mathrm{C}$ to $50{ }^{\circ} \mathrm{C}$, the density of the diode current of saturation increases by $50 \%$ from $1.9 \cdot 10^{9} \mathrm{~A}$ to $2.7 \cdot 10^{9} \mathrm{~A}$, which is lower than for silicon PVC, for which the diode saturation current increases by $300 \%$ [8].

6. K.J. Linden, Proc. SPIE 9, 205 (2016)

7. A.L. Fahrenbruch, R.H. Bube, Fundamentals of Solar Cells (New York: Academic Press Inc.: 1983).

8. R.V.Zaitsev, M.V. Kirichenko, G.S. Khrypunov, L.V.Zaitseva, Renew. Energ. 50 No 3, 35 (2017).

9. V. Perraki, G. Tsolkas, Int. J. Renew. Sustainable Green Energ. 2 No 4, 140 (2013).

10. P. Singh, N.M. Ravindra, Sol. Energ. Mater. Sol. C. 101, 36 (2012).

11. A. Virtuani, D. Pavanello, G. Friesen, 25th European Photovoltaic Solar Energy Conference and Exhibition, 4248 (Spain: Valencia: 2010). 


\title{
Вплив робочої температури на ефективність тонкоплівкових сонячних елементів
}

\author{
Р.В. Зайцев ${ }^{1}$, М.В. Кіріченко ${ }^{1}$, Г.С. Хрипунов 1 , С.А. Радогуз ${ }^{1}$, \\ М.Г. Хрипунов ${ }^{1}$, Д.С. Прокопенко ${ }^{1}$ Л.В. Зайцева ${ }^{2}$
}

\author{
1 Національний технічний університет "Харківський політехнічний інститут", \\ вул. Кирпичова 2, 61002 Харків, Украӥна \\ 2 Національний аерокосмічний університет "Харківський авіаційний інститут», \\ вул. Чкалова, 17, 61000 Харків, Украӥна
}

\begin{abstract}
У роботі розглянуто результати дослідження залежності ефективності плівкових фотоелектричних перетворювачів від їх робочої температури та проведено їх порівняння. Приведено аналіз фізичних механізмів впливу температури на вихідні, діодні та електронні параметри фотоелектричних перетворювачів. Визначення вихідних параметрів гнучких фотоелектричних перетворювачів здійснювалося за допомогою вимірювання світлових вольт-амперних характеристик за допомогою освітлювача на основі потужних напівпровідникових світлодіодів різного кольору для імітаційного випромінювання, характерного для стандартного наземного спектра сонячного світла. Для забезпечення ефективного неруйнівного контакту випробувальних зразків гнучких елементів на основі телуриду кадмію до кола вимірювання розроблено і використано спеціальний контактний пристрій. Головною особливістю контактного пристрою е чотири роздільних вертикально рухомих металевих зонда у вигляді напівсфер з полірованими поверхнями, що унеможливлюе проколювання плівкових електродів. Дані зонди мають можливість індивідуального позиціонування кожного зонда, що здійснюеться за допомогою твердої поворотної консолі змінної довжини, прикріпленої до корпусу. Отримано коефіціенти зниження ефективності від робочої температури фотоелектричного перетворювача, що складають для пристроїв на основі $\mathrm{CdTe}-0.14 \% / \mathrm{C}$, для $\mathrm{CuInSe} 2-0.36 \% / \mathrm{C}$, для аморфного кремнію $-0.21 \% / \mathrm{C}$. Аналітична обробка та аналіз впливу світлових діодних характеристик на ефективність приладів на основі CdTе показали, що температурна стабільність ї ефективності забезпечуеться стабільністю густини діодного струму насичення, величина якого збільшуеться на $50 \%$ з $1.9 \cdot 10^{-9}$ А до $2.7 \cdot 10^{-9}$ А з підвищенням температури від $20^{\circ} \mathrm{C}$ до $50{ }^{\circ} \mathrm{C}$. В той же час для приладів на основі $\mathrm{CuInSe} 2$ та аморфного кремнію встановлено, що основну роль у зниженні ефективності при підвищенні температури має зменшення густини струму короткого замикання, напруги холостого ходу та коефіціента заповнення вольт-амперних характеристик.
\end{abstract}

Ключові слова: Фотоелектричні перетворювачі, Тонкі плівки, ККД, Вихідні та діодні параметри, Робоча температура. 